\title{
Effect of Parameters on Temperature Field of Fin Surface
}

\author{
正 橋詰健一（広島工大） ○学 藤田知浩（広島工大院） \\ 正 松江孝博（広島工大）
}

Kenichi HASHIZUME、Tomohiro FUJITA 、 and Takahiro MATSUE

Hiroshima Institute of Technology, Miyake2-1-1, Saeki-ku, Hiroshima

Key Words : Plane fin, Temperature distribution

\section{1. 緒言}

ハイフィンチューブは、空冷熱交換器や高温ガスからの熱回収な どに広く利用されている。従来のハイフィンチューブは、伝熱面積 を広く得るためにフィンピッチを狭くしたり、フィン高さを高くす ることで多くの熱量を得ていた。近年、フィン先端部に切り込みを 入れたセレーテッドフィンが現れ、切り込みにより周囲流体の流れ を乱し伝熱促進させ多くの熱量を得ている。しかし、それら新型フ インと比較する際に基淮となるプレインフィン表面の温度分布に 関して詳細に述べた論文は極めて少なく。レイノルズ数、管配列、

フィンピッチの影響に関しては不明である。

フィン表面の温度分布が明らかとなれば、フィン表面において伝 熱特性の低い伝熱面に何らかの改良を加えることで伝熱促進が期 待され、新型フィン開発の手掛りを得ることが出来る。そこで、我々 はその基礎研究として諸パラメーターに関するフィン表面の温度 分布を測定し、それらの及ほす影響について調べた。

\section{2. 実験}

2. 1. 実験装置およひ諸パラメーター

図 1 に実験装置の概略図を示す。送風機によりテストセクショ ン内(断面 $250 \times 50[\mathrm{~mm}]$ 、長さ $1000[\mathrm{~mm}]$ )に作動流体としての空 気を送り込む。流量測定はコーナータップオリフィスによる差圧を ベッツ型マノメータで読み取り、JSに基づき算出した。また、流 量調節はバルブを開閉させた。図 2 に千鳥配列における供試フィン チューブの配置図を示す。斜線で示す一体のみが加熱された供試つ インチューブである。周囲空気温度は、 $\mathrm{T}$ 型熱電対をテストセクシ ヨン出入り口の計 3 ヶ所に取り付け、その平均を空気温度とした。

諸パラメーターとして、レイノルズ数は $R e=(1.0 、 2.0 、 3.0) \times$ $10^{4}$ の範用で、管配列は単一、一列配列、千鳥配列、碁盤目配列を 配置し、フィンピッチは $\mathrm{P}=7.0 、 5.0[\mathrm{~mm}]$ を用意した。

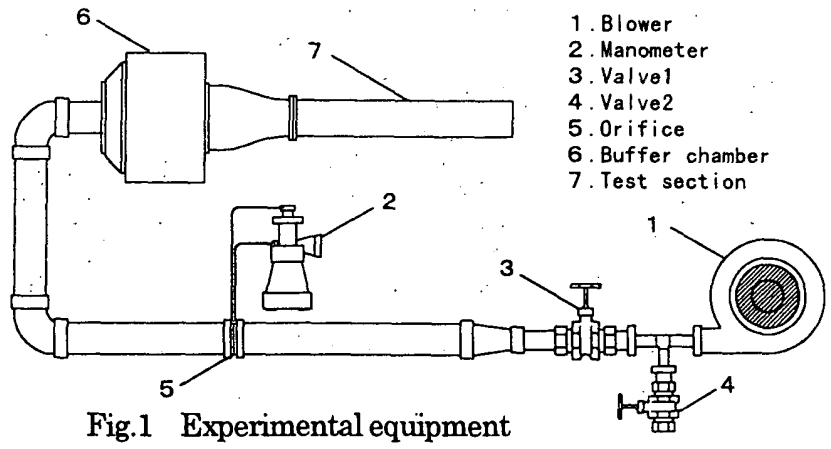

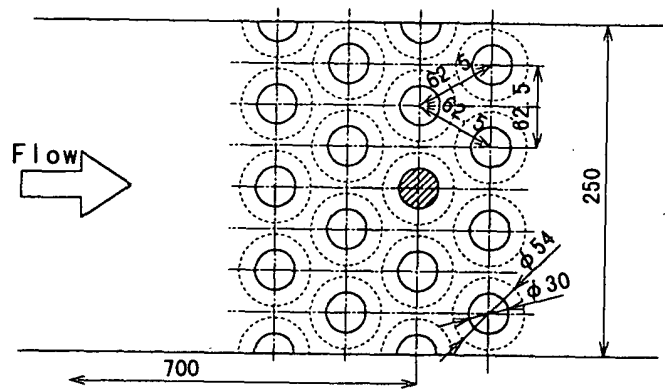

Fig.2 Tube arrangement

\section{2. 供試フィンチューブ}

図 3 に供試フィンチューブと $\mathrm{T}$ 型熱電対取り付け位置を示す。 供試フィンチューブは、カートリッジヒーター(直径 $20.0[\mathrm{~mm}]$ 、加 熱部 $50.0[\mathrm{~mm}])$ にステンレス製のフィン(フィン外径 $54.0[\mathrm{~mm}]$ 、厚 さ $1.0[\mathrm{~mm}])$ とスペーサ(スペーサ外径 $30.0[\mathrm{~mm}]$ 、厚さはフィンピ ッチにより変更)を交互に積み重ねた。また、供試フィンチューブ 以外は全て非爇のダミーフィンチューブである。

フィン表面温度は、 $\mathrm{T}$ 型熱電対(線径 0.2[mm])をフィン表面の 7 ヶ所に取り付け、流れ方向から時計周りに 15[ ]づつ 360[ ]回転 させ測定した。

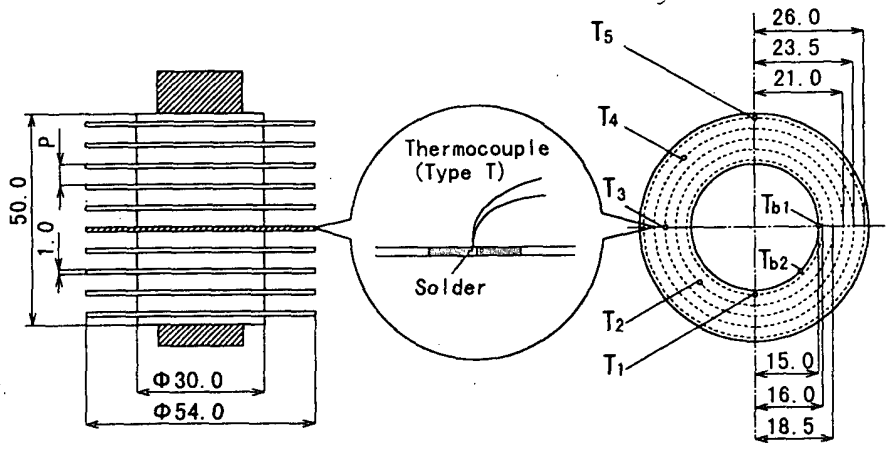

Fig.3 Test tube

\section{3. 結果及び考察}

図 4(a)〜(g)にフィン表面の温度分布を無次元温度比により示す。 これはフィン全表面で熱伝達率を一様として算出した温度差 $\mathrm{T}_{0}[\mathrm{~K}]$ と、伝熱実験により湘定した温度差 $\mathrm{T}[\mathrm{K}]$ の無次元温度比 $\tau^{\prime}=\mathrm{T}_{0}$

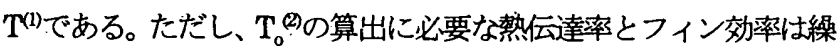
り返し計算から求めた。 
表 1 に温度分布のばらつきを面积侍重栖淮偏差 $\sigma$ により示す。

$$
\begin{aligned}
\sigma^{2} & =\frac{1}{A}\left\{A_{s(1,1)}\left(\tau_{(1,1)}^{\prime}-\bar{X}\right)^{2}+A_{s(2,1)}\left(\tau_{(2,1)}^{\prime}-\bar{X}\right)^{2}+\cdots+A_{s(1, j)}\left(\tau_{(1, j)}^{\prime}-\bar{X}\right)^{2}\right\} \\
\bar{X} & =\frac{1}{A}\left\{A_{s(1,1)} \tau_{(1,1)}^{\prime}+A_{s(2,1)} \tau_{(2,1)}^{\prime}+\cdots+A_{s(1, j)} \tau_{(1, j)}^{\prime}\right\} \\
A & =\left\{A_{s(1,1)}+A_{s(2,1)}+\cdots+A_{s(1, j)}\right\}
\end{aligned}
$$

$\mathrm{X}:$ 面樎何重平均 $[-] \quad \mathrm{A}_{\mathrm{a}}:$ メッシュ表面积 $\left[\mathrm{m}^{2}\right]$

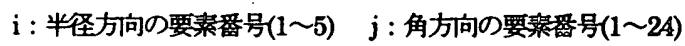

Table.1 Standard deviation

\begin{tabular}{|c|c|c|c|c|c|}
\hline \multicolumn{2}{|c|}{} & \multicolumn{5}{|c|}{ Tube arrangement } \\
\hline $\begin{array}{c}\mathrm{P} \\
{[\mathrm{mm}]}\end{array}$ & $\begin{array}{c}\text { Re } \\
\times 10^{4}\end{array}$ & $\begin{array}{c}\text { Staggered } \\
\text { arrangement }\end{array}$ & $\begin{array}{c}\text { Aligned } \\
\text { arrangement }\end{array}$ & $\begin{array}{c}\text { Single } \\
\text { tube row }\end{array}$ & $\begin{array}{c}\text { Single } \\
\text { tube }\end{array}$ \\
\hline \multirow{3}{*}{5.0} & 1.0 & 0.323 & 0.200 & 0.262 & 0.248 \\
\cline { 2 - 6 } & 2.0 & 0.394 & 0.257 & 0.293 & 0.268 \\
\cline { 2 - 6 } & 3.0 & 0.430 & 0.298 & 0.319 & 0.312 \\
\hline 7.0 & 3.0 & 0.408 & 0.283 & 0.268 & 0.292 \\
\hline
\end{tabular}

レイノルス数の影響からみた場合、千鳥配列の図 4 (a)、(b)、(c) において、高いレイノルズ数ほどフィン前面の先端付近に高い領域 がある。全実験を通して高いレイノルズ数ほど、フィン前面に $\tau \geq 1.3$ の高い領域が広がり、それに伴いフィン背面に $\tau$ ' $\leq 0.7$ の低 い領域が広がる。これは流勳実験おいて、高い流速により周囲流体 の流れを乱すことが要因である。

管配列の影爵からみた場合、レイノルス敨 $R e=3.0 \times 10^{4}$ の図 4 (c)、(d)、(e)、(f)おいて、碁盤目配列ではフィン側面の先端にのみ 高い領域が見られるが、フィン前面・背面に低、領域が広がる。こ れは碁盤目配列の周囲流体流れにおいて、フィン前面・背面に死水 域が存在することが要因である。単一ではフィン背面に不安定な低 い領域が見られる。これは単一の周囲流仵流れたおいて、フィン背 面にカルマン渦が存在することが要因である。一列列列における㷱 伝達率の領域は、フィン前面において単一と穎似し、側面において 千鳥配列と䅡似する。

フィンピッチ影響からみた場合、千鳥配列の図 4(c)、(g) におい て、広いフィンピッチほどフィン先端付近に高い領域がある。これ は流動実験おいて、広いフィンピッチにより周囲流脌流れを乱すこ とが要因である。

\section{4. 結言}

プレインフィン表面の温度分布より、以下のことが言える。

1.レイノルス效による影跑は、高いレイノルス效ほどフィン先 端付近で高い堑伝達淬となる。

2. 管配列による影琴は、周囲流体の流甥样式が变化することに より各配列ごとに特街的な䇾伀造率分布となる。

3.フィンピッチによる影鏭社は広いフィンピッチほど面程荷重 による平均値からの分布割合が小さい。

\section{参考文献}

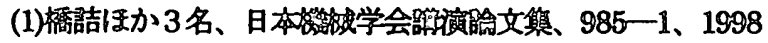

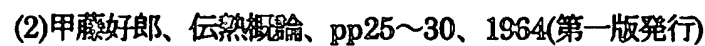

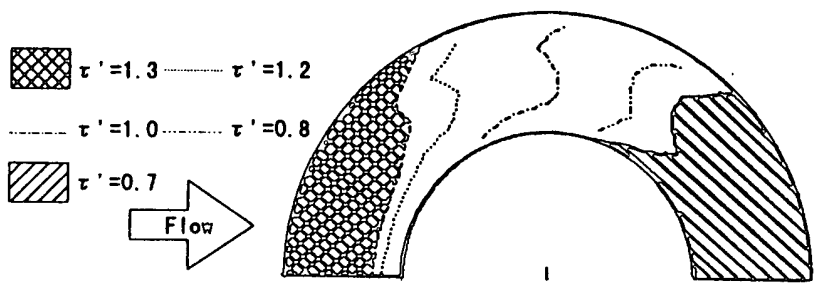

(a)Staggered arrangement $\left(\mathrm{Re}=1.0 \times 10^{4} 、 \mathrm{P}=5\right)$

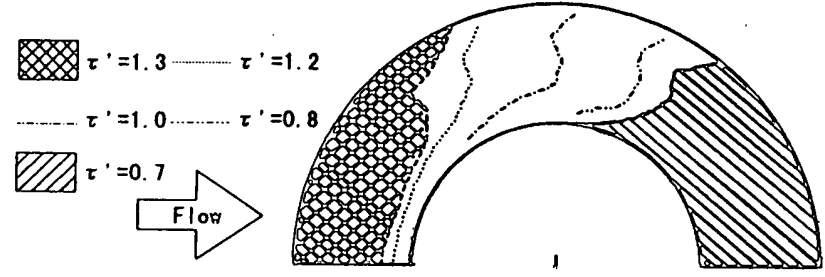

(b)Staggered arrangement $\left(\mathrm{Re}=2.0 \times 10^{4}, \mathrm{P}=5\right)$

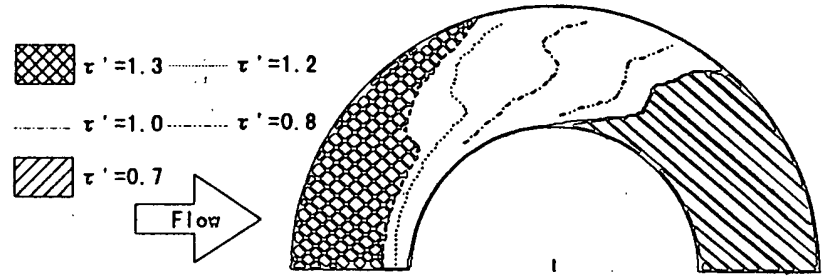

(c)Staggered arrangement $\left(\operatorname{Re}=3.0 \times 10^{4} 、 P=5\right)$

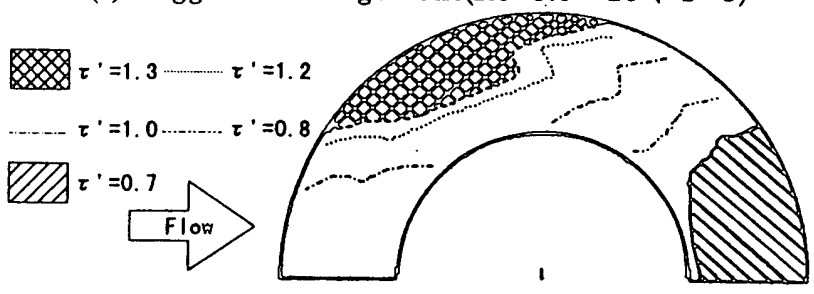

(d)Aligned arrangement $\left(\operatorname{Re}=3.0 \times 10^{4}, P=5\right)$

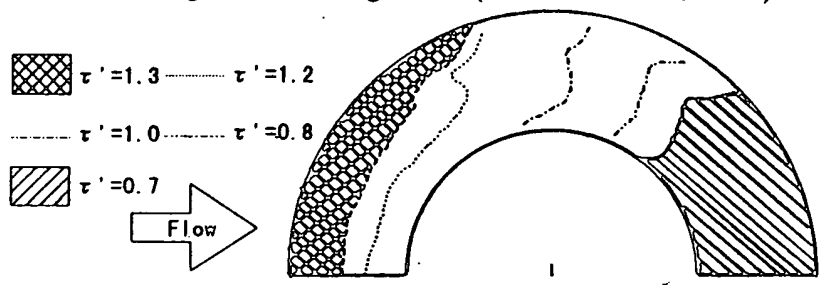

(e) Single tube row $\left(\operatorname{Re}=3.0 \times 10^{4}, P=5\right)$

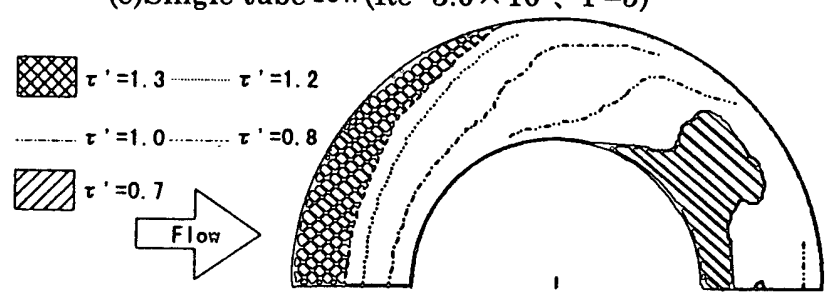

(f) Single tube $\left(\operatorname{Re}=3.0 \times 10^{4} 、 P=5\right)$

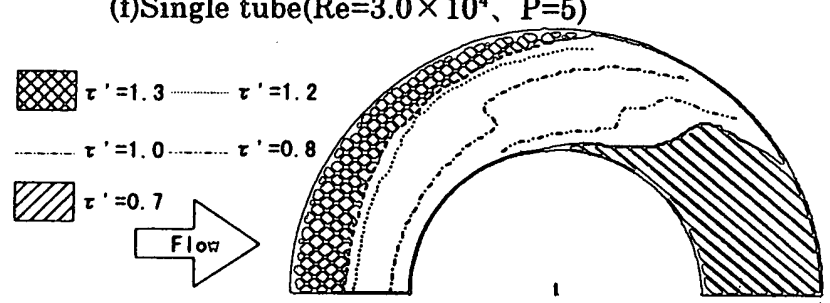

(g)Staggered arrangement $\left(\operatorname{Re}=3.0 \times 10^{4}, P=7\right)$

Fig.4 Temperature distribution 